STRUCTURE AND FUNCTION OF BIOPOLYMERS

UDC 577.323:576.08

\title{
Influence of chloroquine on kinetics of single-cell gel electrophoresis
}

\author{
M. O. Zazhytska, K. S. Afanasieva, M. I. Chopei, M. A. Vikhreva, A. V. Sivolob
}

Educational and Scientific Center «Institute of Biology», National Taras Shevchenko University of Kyiv 64/13, Volodymyrska Str., Kyiv, Ukraine, 01601

sivolob@univ.kiev.ua

\begin{abstract}
In single-cell gel electrophoresis (the comet assay) the DNA of lysed cells, the nucleoids, extends towards the anode in a track resembling a comet tail. The aim of this work was to investigate the effects of changes in DNA topology on this process. Methods. We used the kinetic approach, proposed earlier by us, to measure a relative amount of DNA in the comet tails as a function of time in the presence of different concentrations of chloroquine, a widely used intercalator. Results. We have shown that, at given small concentrations, intercalation of chloroquine strongly facilitates the comet tail formation. At the same time, some part of DNA (about $8 \%$ ) in the nucleoids exits very fast independently on chloroquine, while the largest part of DNA (about three quarters) does not exit at all. At high concentrations the intercalator increases the fraction of DNA, which cannot exit. Conclusions. Our results imply that the loop domains, which contain about one to several hundreds kilobases, represent only a small part (about a quarter) of DNA in the nucleus. The intercalation induces detachment of these loops from the nuclear matrix.
\end{abstract}

Keywords: comet assay, chloroquine, intercalation, DNA loops, supercoiling.

Introduction. Single-cell gel electrophoresis (the comet assay) is a widely used sensitive technique to evaluate the rate of DNA damages and their repair kinetics in individual cells [1-4]. To perform the assay cells are embedded in a thin layer of agarose on a microscope slide and then lysed to produce nucleoids - negatively supercoiled DNA loop domains attached to the nuclear matrix $[3,5]$. It is very often assumed that all the DNA in the nucleus is organized in such loops containing from a half to several hundreds kilobases. Under electric field the DNA migrates towards the anode forming an electrophoretic track, which resembles a comet tail and can be visualized by fluorescent microscopy.

Although the comet assay is usually considered to be eminently suitable for estimation of DNA damages, for a long time there was no consensus on nature of DNA that forms the comet tail [6]. In numerous experiments DNA exit from nucleoids was significantly facilitated when cells were exposed to DNA damaging agents. The-

(C) Institute of Molecular Biology and Genetics, NAS of Ukraine, 2012 se observations led to the conclusions that, upon single strand breaks accumulation, the comet tail can be formed whether by linear DNA fragments or relaxed DNA loops attached to the nuclear matrix $[1,4,6]$. We have shown in our previous studies that both possibilities may be realized depending on the damage level and electrophoresis conditions $[7,8]$. In particular, in our experiments on the kinetics of the comet formation in intact (undamaged) cells the comet tail was effectively formed after long electrophoresis duration. In this case the tail clearly contains nothing but supercoiled DNA loops, which are extended to the anode. This interpretation was confirmed by observation that DNA exit is reversible after switching off electrophoresis [7,8].

Moreover, an alteration of DNA supercoiling by ethidium bromide $(\mathrm{EtBr})$ intercalation essentially influenced the rate of DNA exit in intact cells. At the appropriate concentration of $\operatorname{EtBr}(0.05 \mu \mathrm{g} / \mathrm{ml})$ the DNA exit was observed to be facilitated significantly due to unwinding of the double helix and, respectively, removal of the negative DNA torsional constraint. After further 
increase in EtBr concentration the exit was again hampered, presumably due to the accumulation of positive supercoiling in the loop domains [8]. It was suggested that the comet assay performed in the presence of an intercalator gives a possibility to estimate the level of DNA supercoiling in nuclei.

We investigated the influence of another intercalator, chloroquine, on the kinetics of DNA exit in the comet assay. In contrast to our previous studies where the fraction of cells with the tails was measured, here we used the relative amount of DNA in the tails, the parameter which is more straightforward. Since, in comparison with $\mathrm{EtBr}$, the affinity of chloroquine to DNA is considerably lower this intercalator appears to be more sensitive to detect the DNA supercoiling level. In addition, measuring the relative amount of DNA in the tails allowed us to observe three kinds of the loop domains: (i) loops that exit very fast independently on the chloroquine concentration; (ii) loops that are sensitive to chloroquine, the exit of which is facilitated at low concentrations and hampered at high concentrations of the intercalator; and (iii) loops that do not exit at all. We discuss an insight, which is provided by our results into the problem of topological organization of chromatin in the cell nucleus.

Materials and methods. Sample preparation. Human peripheral blood was collected into heparinized medical syringe from healthy donors by finger-pricking. Lymphocytes were separated by centrifugation in a density gradient («Granum», Ukraine) and then washed in $0.15 \mathrm{M} \mathrm{NaCl}$ twice. $50 \mu 1$ of the suspension obtained was mixed with $100 \mu 1$ of $1 \%$ low melting point agarose («Sigma», USA) at $37{ }^{\circ} \mathrm{C}$. Aliquots of $25 \mu 1$ of the mixture were placed on microscope slides, which were preliminarily covered with thin layer of $1 \%$ highmelting point agarose («Chemapol», Czech Republic). After 5 min of agarose polymerization at $4{ }^{\circ} \mathrm{C}$, slides were immersed in ice-cold lysis solution $(2.5 \mathrm{M} \mathrm{NaCl}$, $100 \mathrm{mM}$ EDTA, $10 \mathrm{mM}$ Tris- $\mathrm{HCl}$ (pH 8.0), and $1 \%$ Triton $\mathrm{X}-100$ («Ferak», Germany), which was added just before use) for $3 \mathrm{~h}[2,9]$.

The comet assay. Electrophoresis was conducted in TBE buffer ( $89 \mathrm{mM}$ Tris-borat, $2 \mathrm{mM}$ EDTA, $\mathrm{pH}$ 7.5) at $4{ }^{\circ} \mathrm{C}(1 \mathrm{~V} / \mathrm{cm}, 300 \mathrm{~mA})$. The comet assay was usually performed in the presence of chloroquine («Sigma»), which was added to the electrophoresis buffer at different concentrations. In all experiments we measured the kinetics of comet formation: several slides, which were simultaneously prepared in the same way, were placed into the electrophoresis tank, and then they were taken out for further analysis with interval of $10 \mathrm{~min}$.

Comet scoring and analysis. Slides were stained with $1.3 \mu \mathrm{g} / \mathrm{ml}$ of DAPI (4',6-diamidino-2-phenylindole, «Sigma») and immediately analyzed with a fluorescent microscope («LOMO», Russian Federation) connected with a camera Canon EOS 1000 D. A total 100 200 randomly chosen cells on each slide were examined using image analysis software CometScore («TriTec», USA) to determine the relative amount of DNA in the tails defined as the ratio of the tail fluorescence intensity to the total intensity of the comet.

Binding of chloroquine to DNA was measured from changes in chloroquine absorption spectrum [10]. High-molecular-weight salmon testes DNA («Sigma») in TBE buffer was titrated by chloroquine stock solution in the same buffer and the optical density at $343 \mathrm{~nm}$ was measured with a spectrophotometer (SF-46, «LO$\mathrm{MO} »)$. Initial DNA concentration was measured spectrophotometrically taking the extinction coefficient $13,200 \mathrm{M} \mathrm{(bp})^{-1} \mathrm{~cm}^{-1}$ at $260 \mathrm{~nm}$. The extinction coefficient of chloroquine free in solution at $343 \mathrm{~nm}$ was found to be $\varepsilon_{f}=14,000 \mathrm{M}^{-1} \mathrm{~cm}^{-1}$. The extinction coefficient of totally bound chloroquine measured in the presence of a large excess of DNA was estimated to be $\varepsilon_{b}=4,100 \mathrm{M}^{-1} \mathrm{~cm}^{-1}$. The fraction $\phi$ of bound ligand is given by:

$$
\phi=\left(\varepsilon_{f} C-A\right) /\left(\varepsilon_{f} C-\varepsilon_{b} C\right),
$$

where $C$ is the total concentration of chloroquine; $A$ is the optical density measured. Only data points corresponding to $\phi$ between 0.2 and 0.8 were taken into account. With $C_{D N A}$ being the total concentration of DNA in solution, free chloroquine concentration is $L=(1-\phi) C$, while chloroquine binding density (number of ligand molecules bound per base pair) is $\mathrm{v}=\phi C / C_{D N A}$ According to the model for non-cooperative excluded site binding derived by McGhee and von Hippel [11], the equation for the binding isotherm can be written as:

$$
\mathrm{v}=K L \frac{(1-n \mathrm{v})^{n}}{(1-n \mathrm{v}+\mathrm{v})^{n-1}},
$$

where $K$ is the binding constant; $n$ is the size of the binding site (the number of base pairs excluded to another li- 
gand by each bound molecule). To estimate the parameters this equation was fitted to the experimental data using a standard non-linear least-squares fitting routine.

Results and discussion. Fig. 1, $a$, shows the kinetics of DNA exit from intact non-damaged lymphocytes as it was observed at neutral $\mathrm{pH}$ without intercalators. An example of comets is presented in Fig. 1, $b$ : in all our experiments, practically independently on electrophoresis duration, there were no changes in the comet morphology. In particular, the average length of the comet tail was approximately equal to $50 \mu \mathrm{m}$, which corresponds to the contour length of an extended loop to be not more than about $300 \mathrm{~kb}$.

The kinetic plot in Fig. 1, $a$, clearly has a two-step shape. The first step reflects some small part of DNA (the relative amount of DNA in the comet tails does not exceed 0.08 up to $30^{\text {th }} \mathrm{min}$ ), which exits very rapidly (the first plateau is reached in about $10 \mathrm{~min}$ ). The existence of the first step was implied by our previous results [7, 8], but now, when the amount of DNA in the tails is measured instead of the fraction of cells with the tails, this effect is much more pronounced. The second step is sigmoid: the exit of a larger part of DNA (about 0.14) is observed between $30^{\text {th }}$ and $50^{\text {th }} \mathrm{min}$. Then the relative amount of DNA in the tails $(0.08+0.14=0.22)$ remains constant up to $80^{\text {th }} \mathrm{min}$. Thus, the DNA exit during the comet assay is stepwise: a rapid component forms the lower plateau and a slow component additionally contributes to the higher plateau.

Our previous works confirmed the idea that the comet tail is formed by extended DNA loops, the exit of which is considerably facilitated when they are relaxed [8]. Thereby, it is possible to postulate that the lower plateau in Fig. 1, $a$, is formed by a small amount of «rapid loops» with single-strand breaks, which naturally occur in terminally differentiated cells. Since such loops are relaxed they have to exit rapidly. When the electric force is applied for a longer time an extension of intact (and, respectively, supercoiled) DNA loops occurs. On their way towards the anode, these loops have to overcome, except agarose resistance, their own torsional constraint: the negative torsion deformations appear in the loops when they are stretched by the electric force. Thus, the negatively supercoiled "slow loops» give the main contribution to the higher plateau on the kinetic plot in Fig. 1, $a$.

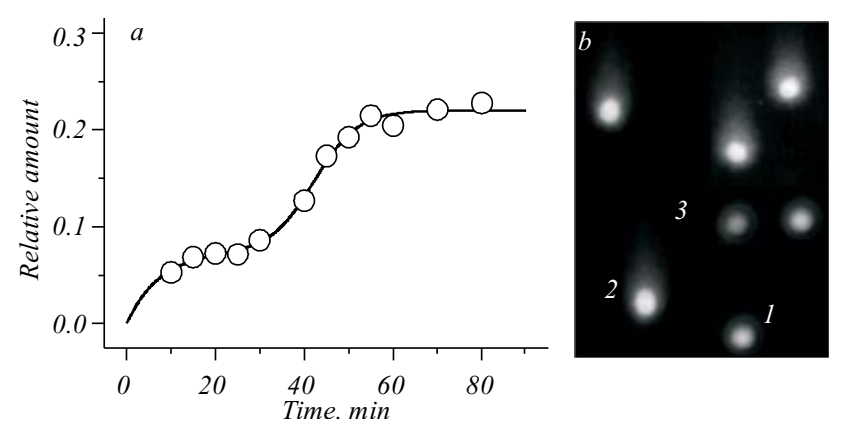

Fig. 1. The relative amount of DNA in the comet tails as a function of electrophoresis duration in the absence of chloroquine $(a)$ and a typical example of the comet appearance $(b)$, the nucleoids without (1) and with the tails $(2,3)$ are indicated. In part $(a)$ and in figures below each point represents an average for 3 to 7 independent experiments, continuous curve is a result of an interpolation

If the «slow loops» would be relaxed their exit would be facilitated. The relaxation can be achieved due to partial DNA unwinding upon binding of an intercalator. In total accordance with our previous results obtained with EtBr $[7,8]$, an essential acceleration of DNA exit was observed in the presence of some concentrations of chloroquine (Fig. 2). The acceleration begins already at very low chloroquine concentration $(5 \mu \mathrm{g} / \mathrm{ml})$, and then it becomes more pronounced at the concentrations 10 (not shown), 25 and $50 \mu \mathrm{g} / \mathrm{ml}$. The two-step kinetics, described above for the case when the intercalator is absent, disappears and the relative amount in the tail reaches the higher plateau in one step (in about $10 \mathrm{~min}$ ): the rapid and slow components mentioned above become indistinguishable. In other words, the supercoiled loops, which are relaxed in the presence of chloroquine, exit as fast as the loops with single strand breaks do (clearly, the loops with the breaks are relaxed already and should not be sensitive to the topological changes introduced by intercalation).

Further gradual increase in the chloroquine concentration (and respectively in the binding density of the ligand) is accompanied by two effects: a slowdown in the DNA exit and a decrease in the saturation level (Fig. 2). The same effect was observed earlier with $\mathrm{EtBr}[7,8]$. It is interesting that at very high concentrations (500 and $1000 \mu \mathrm{g} / \mathrm{ml}$ ) the two-step behavior appears again.

Fig. 3 shows another representation of the dependence of the rate of DNA exit upon chloroquine concentration: the relative amount of DNA in the tails after $10 \mathrm{~min}$ of electrophoresis. The chloroquine concentrations in the ranges from about 20 to $50 \mu \mathrm{g} / \mathrm{ml}$ appear to be the most 


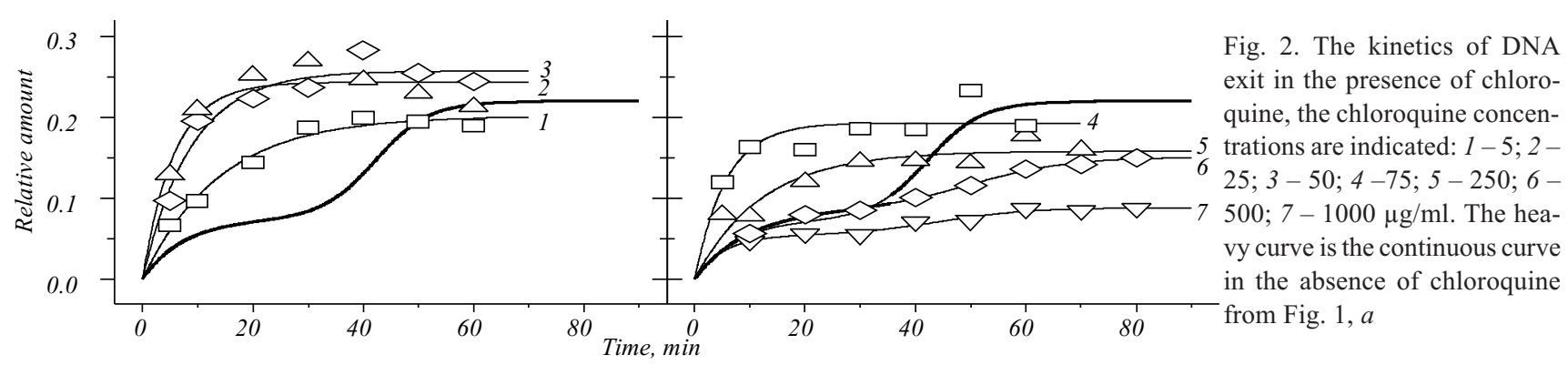

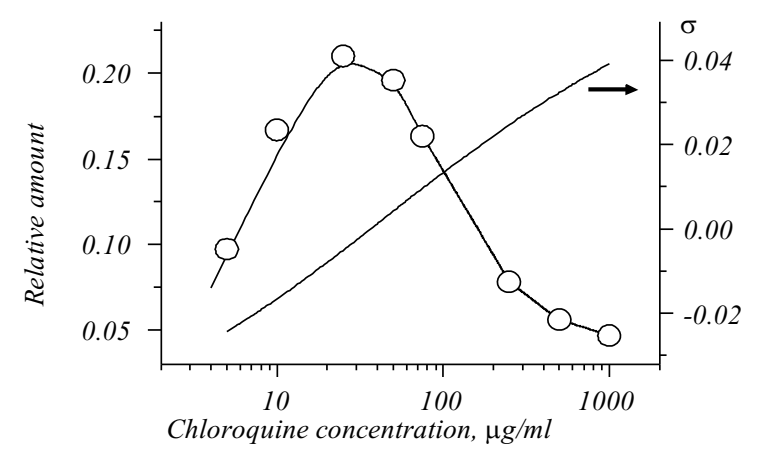

Fig. 3. The relative amount of DNA in the tails after 10 min of electrophoresis and the net supercoiling density $\sigma$ in the loops (see text for details) as functions of chloroquine concentration

effective in the acceleration of DNA exit. It should be noticed that the two plots in Fig. 2 for 25 and $50 \mu \mathrm{g} / \mathrm{ml}$ are practically identical while the chloroquine concentrations differ about twofold. Perhaps, it reflects a heterogeneity in the level of DNA supercoiling for the chromatin loops in the nucleus.

With the purpose to get quantitative information about the supercoiling level compensated by such chloroquine concentrations, we have obtained the isotherm for chloroquine binding to high-molecular-weight DNA in the conditions of the comet assay (see «Materials and methods»). It was found after analysis of the isotherm (not shown) that in TBE buffer the binding constant $K=(2.4 \pm$ $\pm 0.4) \cdot 10^{3} \mathrm{M}^{-1}$ and the apparent size of the binding site $n=4.4 \pm 0.4 \mathrm{bp}$.

The binding site of chloroquine is larger than that of $\mathrm{EtBr}(\sim 2.5 \mathrm{bp}[12])$ presumably because of higher charge ( +2 for chloroquine against +1 for EtBr at neutral $\mathrm{pH})$. The binding constant is about two orders lower for chloroquine in comparison with $\mathrm{EtBr}[8,12]$, which explains that the most effective $\mathrm{EtBr}$ concentration to accelerate the DNA exit is about 100 times lower [8] than the chloroquine concentrations mentioned above. That makes chloroquine more sensitive to resolve the DNA supercoiling level.
Using the parameters of chloroquine to DNA binding it is possible to estimate the chloroquine binding density for different concentrations used in the comet assay. To describe the chloroquine binding to circular DNA (which is equivalent to the loop domain) Eq. 1 should be re-written [13]:

$$
\mathrm{v}=K L \frac{(1-n \mathrm{v})^{n}}{(1-n v+v)^{n-1}} \exp \left(2 A\left(\mathrm{v}_{0}-\mathrm{v}\right)\right)
$$

where the free chloroquine concentration $L$ is equal to its total concentration in the electrophoresis buffer in our experiments; $A \approx 5[12,13]$ is the modified supercoiling force constant; $\mathrm{v}_{0}=-360^{\circ} \sigma_{0} /(\theta h)$ is the binding density corresponding to the total relaxation of the initial negative supercoiling. In the last relation $v_{0}$ is the initial (before an addition of the intercalator) supercoiling density in the loop, $\theta \approx 17^{\circ}$ is the chloroquine unwinding angle [14], and $\mathrm{h} \approx 10.5$ bp per turn is the DNA helical periodicity. At $v=v_{0}$ the exponential term turns into unity and the equation becomes equivalent to Eq. 1 that describes binding to linear DNA.

Since the chloroquine concentrations 25 to $50 \mu \mathrm{g} / \mathrm{ml}$ correspond to the relaxation (when the binding density $v \approx v_{0}$ and the net supercoiling density $\sigma \approx 0$ ), then according to Eq. 1 using the values of $K$ and $n$ mentioned above the binding density can be estimated to be 0.07 to 0.09 . It means that the corresponding initial supercoiling density $\sigma_{0}=-v_{0} \theta h / 360^{\circ}$ is in the ranges from about -0.035 to -0.045 . These values are quite expected for the loops after removal of nucleosomes.

Taking the average $\sigma_{0} \approx-0.04$, we can estimate the net supercoiling density in the loops at different chloroquine concentrations $\sigma=\sigma_{0}+\sigma_{E}$, where $\sigma_{E}=v \theta h / 360^{\circ}$ is the supercoiling density introduced by the intercalator and $v$ obeys Eq. 2. The result is presented in Fig. 3 . Note, that the absolute value of positive supercoiling density at the highest chloroquine concentrations is approximately the same as that of the initial negative su- 
percoiling density. Hence, the slowdown in the DNA exit, which occurs when the chloroquine concentration increases beyond $50 \mu \mathrm{g} / \mathrm{ml}$, can be explained by the accumulation of positive supercoiling due to intercalation: the rate of the exit at the highest concentrations of chloroquine is about the same as in the absence of the intercalator (Fig. 2, 3).

At the same time, the main effect of the high concentrations of chloroquine is the gradual decrease in the maximum amount of DNA in the tails that can be reached after long time of electrophoresis (Fig. 2). This effect cannot be explained by an increase in positive supercoiling, since, in comparison with the case without the intercalator, the supercoiling increases up to the same absolute values but the saturation level becomes much lower (Fig. 2). Some additional contributions into the hampering of the DNA exit may come from the changes in charge, contour length and stiffness of DNA upon binding of intercalators $[15,16]$.

More probably, however, all this factors (taking into account that according to our estimations the binding density of chloroquine equals to $\sim 0.16$ at 1000 $\mu \mathrm{g} / \mathrm{ml}$ ) have to contribute into delay of the exit, not into the hampering.

In our opinion, the most attractive explanation of the hampering of the exit in the presence of high concentrations of chloroquine is related to a non-trivial observation, which was not discussed yet. Our experiments allow us to discriminate between the two kinds of the loops referred to as the rapid and slow components. But there is obviously a third component: the loops that do not exit ever. In all our experiments with intact cells the maximum relative amount of DNA in the tails did not exceed 0.25 (rarely in some samples it reached 0.3). This means that the comet tail composed of the DNA loops (relaxed or not), represents only small part (not more than a quarter) of DNA in the nucleus.

Only for heavily damaged cells, as it is well known, the relative amount in the tail may reach 0.7 to 0.8 or even 1 [17-19]. But in this case the tail contains linear DNA fragments attached to or/and detached from the nuclear matrix [8].

The loops, which cannot exit during electrophoresis, are, more probably, simply the loops, which are too large. Then the hampering of the DNA exit by an intercalator at high concentrations would mean an increase in the length of such loops due to decrease in the number of loops that may exit. In other words, the local intercalation (which is accompanied by the double helix unwinding) around the sites of the attachment of DNA to the matrix may probably break the interaction with the matrix.

This effect may have something in common with our earlier observation that the total DNA unwinding caused by $\mathrm{NaOH}$ makes it absolutely impossible to form the comet tail, probably because of detachment of the loops from the nuclear matrix $[8,20]$. In the case of chloroquine we apparently deal with «gentler» detaching of DNA loops from the matrix due to local unwinding of the double helix in the attachment sites. This detaching, in turn, enlarges the size of the loop domains and, respectively, causes impossibility for them to exit. Gradual increase in the chloroquine concentration increases the probability of the detaching for growing number of the DNA loops.

Conclusions. The results and notions of this work can be summarized as follows.

1) In neutral comet assay a relaxation of DNA negative supercoiling in nucleoids due to intercalation strongly facilitates the comet tail formation. When the intercalation dependent relaxation is complete (at a given concentration of an intercalator) the facilitation reaches a maximum; at higher concentrations the intercalator creates a hindrance for the tail formation, so that the maximum level of DNA in the tails becomes inaccessible.

(2) The kinetics of the comet tail formation in the presence of an intercalator can be used to estimate the topological state (the supercoiling level) of DNA in nuclei of different cells in different functional states. Chloroquin may be considered as one of the most suitable intercalators for this purpose.

(3) Our results imply that the loop domains, which contain about one to several hundreds kilobases and can exit from the nucleoids during the comet assay, represent only a small part (about a quarter) of DNA in the nucleus. The process of intercalation induces detachment of these loops and, doing so, increases the fraction of very large loops that cannot move during electrophoresis.

Acknowledgements. The authors thank A. Mazur for excellent technical assistance. 
М. О. Зажииька, К. С. Афанасьєва, М. I. Чопей, М. А. Вихрєва, А. В. Сиволоб

Вплив хлорокіну на кінетику електрофорезу ізольованих клітин

Резюме

При електрофорезі ізольованих клітин (кометному електрофорезі) ДНК виходить з лізованих клітин (нуклеоїдів) у напрямку до аноду, утворюючи трек, що нагадує хвіст комети. Мета роботи полягала у вивченні впливу топологічних змін у ДНК на цей процес. Методи. Використано запропонований нами раніше кінетичний nідхід для вимірювання відносного вмісту ДНК у хвостах комет залежно від часу за присутності різних концентрацій хлорокіну одного з відомих інтеркаляторів. Результати. Показано, що за певних низьких концентрацій інтеркаляція хлорокіну суттєво прискорює формування хвостів комет. 3 іншого боку, невелика кількість ДНК нуклеоїдів (близько 8 \%) виходить дуже швидко незалежно від хлорокіну, тоді як більша частина (приблизно три чверті) - не виходить взагалі. За високих концентрачій інтеркалятора зростає ия нездатна до виходу частина ДНК. Висновки. Одержані результати вказують на те, що петельні домени, які містять від однієї до кількох сотень пар основ, представляють лише малу частину (близько чверті) усієї ДНК нуклеоїда. Інтеркаляція спричиняє від 'єднання иих петель від ядерного матриксу.

Ключові слова: кометний електрофорез, хлорокін, інтеркаляиія, петлі ДНК, надспіралізачія.

М. О. Зажиикая, К. С. Афанасьева, М. И. Чопей, М. А. Вихрева, А. В. Сиволоб

Влияние хлорокина на кинетику электрофореза изолированных клеток

\section{Резюме}

При электрофорезе изолированных клеток (кометном электрофорезе) ДНК выходит из лизированных клеток (нуклеоидов) в направлении анода, формируя трек, напоминающий хвост кометы. Цель работы состояла в изучении влияния топологических изменений в ДНК на этот проиесс. Методы. Использован предложенный нами ранее кинетический подход для измерения относительного содержания ДНК в хвостах комет в зависимости от времени в присутствии различных кониентраций хлорокина - одного из известных интеркаляторов. Результаты. Показано, что при определенных низких кониентрачиях интеркаляиия хлорокина существенно ускоряет формирование хвостов комет. С другой стороны, небольшое количество ДНК нуклеоидов (около $8 \%$ ) выходит очень быстро независимо от хлорокина, тогда как большая часть (приблизительно три четверти) - не выходит вообще. При высоких кониентрациях интеркалятора увеличивается эта неспособная к выходу часть ДНК. Выводы. Наши результаты указывают на то, что петельные домены, содержащие от одной до нескольких сотен пар нуклеотидов, составляют только малую часть (около четверти) всей ДНК нуклеоида. Интеркаляция вызывает отсоединение этих петель от ядерного матрикса.

Ключевые слова: кометный электрофорез, хлорокин, интеркаляция, петли ДНК, сверхспирализачия.

\section{REFERENCES}

1. Olive P. L. The comet assay. An overview of techniques // Methods Mol. Biol.-2002.-203.-P. 179-194.

2. Collins A. R. The comet assay for DNA damage and repair: principles, applications, and limitations // Mol. Biotechnol.-2004.26, N 3.-P. 249-261.
3. Dusinska M., Collins A. R. The comet assay in human biomonitoring: gene - environment interactions // Mutagenesis.-2008.23, N 3.-P. 191-205.

4. Collins A. R., Oscoz A. A., Brunborg G., Gaivao I., Giovannelli L., Kruszewski M., Smith C. C., Stetina R. The comet assay: topical issues // Mutagenesis.-2008.-23, N 3.-P. 143-151.

5. Cook P. R., Brazell I. A., Jost E. Characterization of nuclear structures containing superhelical DNA// J. Cell Sci.-1976.-22, N 2.-P. 303-324.

6. Shaposhnikov S. A., Salenko V. B., Brunborg G., Nygren J., Collins $A$. $R$. Single-cell gel electrophoresis (the comet assay): loops or fragments? // Electrophoresis.-2008.-29, N 14.-P. 30053012 .

7. Afanasieva K. S., Shuvalova T. A., Zazhytska M. O., Sivolob A. V. Reversibility of DNA loops exit during single cell gel electrophoresis // Biopolym. Cell.-2008.-24, N 2.-P. 105-111.

8. Afanasieva K., Zazhytska M., Sivolob A. Kinetics of comet formation in single-cell gel electrophoresis: loops and fragments // Electrophoresis.-2010.-31, N 3.-P. 512-519.

9. Olive P. L., Banath J. P. The comet assay: a method to measure DNA damage in individual cells // Nat. Protoc.-2006.-1, N 1.P. 23-29.

10. Cohen S. N., Yielding K. L. Spectrophotometric studies of the interaction of chloroquine with deoxyribonucleic acid // J. Biol. Chem.-1965.-240, N 7.-P. 3123-3131.

11. McGhee J. D., von Hippel P. H. Theoretical aspects of DNAprotein interactions: co-operative and non-co-operative binding of large ligands to a one-dimensional homogeneous lattice // J. Mol. Biol.-1974.-86, N 2.-P. 469-489.

12. Sivolob A., De Lucia F., Revet B., Prunell A. Nucleosome dynamics II. High flexibility of nucleosome entering and exiting DNAs to positive crossing. An ethidium bromide fluorescence study of mononucleosomes on DNA minicircles // J. Mol. Biol.-1999.285, N 3.-P. 1081-1099.

13. Bauer W., Vinograd J. Interaction of closed circular DNA with intercalative dyes II. The free energy of superhelix formation in SV40 DNA // J. Mol. Biol.-1970.-47, N 3.-P. 419-435.

14. Jones R. L., Lanier A. C., Keel R. A., Wilson W. D. The effect of ionic strength on DNA-ligand unwinding angles for acridine and quinoline derivatives // Nucleic Acids Res.-1980.-8, N 7.P. 1613-1624.

15. Reese H. R. Effects of DNA charge and length on the electrophoretic mobility of intercalated DNA // Biopolymers.-1994.-34, N 10.-P. 1349-1358.

16. Sigmon J., Larcom L. L. The effect of ethidium bromide on mobility of DNA fragments in agarose gel electrophoresis // Electrophoresis.-1996.-17, N 10.-P. 1524-1527.

17. Hilger I., Rapp A., Greulich K. O., Kaiser W. A. Assessment of DNA damage in target tumor cells after thermoablation in mice // Radiobiology.-2005.-237, N 2.-P. 500-506.

18. Sullivan R., Graham C. H. Hypoxia prevents etoposide-induced DNA damage in cancer cells through a mechanism involving hypoxia-inducible factor $1 / /$ Mol. Cancer Ther.-2009.-8, N 6.P. 1702-1713.

19. Barker G. F., Manzo N. D., Cotich K. L., Shone R. K., Waxman A. $B$. DNA damage induced by hyperoxia: quantitation and correlation with lung injury // Am. J. Respir. Cell Mol. Biol.-2006.-35, N 3.-P. 277-288.

20. Afanas'eva K. S., Zazhytskaia M. O., Sivolob A. V. Mechanisms of DNA exit during neutral and alkaline comet assay // Tsitol. Genet.-2009.-43, N 6.-P. 3-7.

Received 12.04.12 